\title{
KEYWORDS
}

\section{Critical Ethnic Studies}

\author{
Chandan Reddy
}

O

ritical ethnic studies interrogates positivist US liberal understandings of race within the broader materialist conversation of political modernity as a global social formation. Gathering together a broad variety of critiques of positivist political practices, it observes that disciplinary knowledges centrally mediate our contemporary social formation, regulatively tying the formal "appearance" of race to the national state. It asserts that the liberal positivism that saturates disciplinary and socially hegemonic ways of knowing produces race as an instrumentality of modernity, making race within political modernity nearly identical in meaning and position to violence itself. Both race and violence are defined as effects of contingent practices and historical differences distinct from the epistemological and formal structures of the political sphere they helped inaugurate. In contradistinction, race can be considered the social and discursive "appearance" of the material conditions of possibility that saturate disciplinary expressions and practices of knowledge, neither an error nor an object of knowledge in the proper sense. Yet especially in relation to gender and sexuality, race can be affirmed as a valuable critical tool, as the medium for encountering "alternative contingencies" immanent to normative modernity that remain effectively repressed by the modern disciplinary subject of knowledge. Crucially linked to modern violence, race then also designates a specific field of politics generated by modern knowledge.

Critical ethnic studies offers us access to an oppositional understanding of political modernity, the politics of knowledge, and the persistent re-emergence of racialized cruelty and extreme violence. By repositioning slavery, empire, wars, land seizures, deportations, and racialized immigrations as crucial and ongoing resignifications of the racial nation's dependence upon "fictive ethnicity," critical ethnic studies provides a genealogy of juridical equality and state-based and state-enforced understandings of freedom. It is a genealogy that narrates state-

\footnotetext{
Chandan Reddy is an associate professor of English and gender and sexuality studies at the University of Washington, Seattle. He is the author of Freedom with Violence: Race, Sexuality, and the US State, which won the Alan Bray Memorial Award for Queer Studies from the MLA and the Best Book in Cultural Studies from the Asian American Studies Association. He is currently at work on a new book, Burials of Globalization: Race, Rights and the Failures of Culture.
}

Kalfou, Volume 1, Issue 1 (Spring 2014). (C) 2014 by the Regents of the University of California. ISSN 2151-4712 (print). ISSN 2372-0751 (online). http://dx.doi.org/10.15367/kf.v1i1.21. All rights reserved. 
based freedoms as conserving, even as they produce anew, the racial and gendered inequalities for which these freedoms historically have been an alibi. Indeed, for much of US history, the state enforced a form of bourgeois freedom that liberalism would dub a "freedom from violence." This is the freedom upon which racial, patriarchal, capitalist, and slave-holding rights of enjoyment are predicated. ${ }^{1}$ Throughout the nineteenth and early twentieth centuries, race was figured as the central violence to be negated, cancelled, and unpreserved in the dialectic of modern freedom. Even in the late twentieth century, the era of formal juridical equality, race continues to figure in liberal and national projects in ways that expand surprisingly the state's identity as the guarantor of a modernity free from arbitrary, irrational, and, namely, racial violence.

From the genealogical perspective afforded us through critical ethnic studies, we notice that the state form across the twentieth century sought to address race through its inclusion in the juridical and liberal forms of egalitarian freedom and its apparatuses. Far from diminishing a modern figuration of race as that which calls into being the political state as a counter-violence to race, we see the inverse to be true: at the end of the twentieth century, racial inclusion into the US state form has in important ways expanded and made more complex material racial and racialized, gendered inequalities, while at the same moment expanding the apparatuses of legitimate violence to do the work of securing and reproducing those inequalities through the very institutional sites, occasions, and acts that ensure racial inclusion. This is so much the case that in our current moment, the institutional practices of racial inclusiveness are indistinguishable from what Ruth Wilson Gilmore calls the racialized workfare-warfare state that promulgates the structured asymmetries and divisions of contemporary racial capitalism. ${ }^{2}$

Critical ethnic studies builds on earlier oppositional ethnic studies practices, but deepens their comparative and intersectional work in a contemporary capitalist context characterized by a gendered transnationalization of previously national capitalist economic, institutional, and social practices. ${ }^{3}$ Exceeding the parameters of liberal and nationalist modes of framing both social formations and movements for social change, critical ethnic studies seeks to understand race within the dynamic relations of the national within the international, of the nation form in conditions of empire, and of the microphysics of power that attend a Western context defined by national sovereignty and advanced technological and institutional conditions of capitalist social production and national "defense."

Emanating from women of color and Third World feminisms, queer of color theorizations, and anti-prison, indigenous, "immigrant," and diasporic counterglobalization activism and scholarship, critical ethnic studies interrogates US modern sovereignty, or freedom as legitimate violence, seeing in it the means for growing the "legitimate" force relations of the racialized liberal state, even as the current global capitalist practices to which this state contributes undermine the 
liberal thesis of territoriality by which sovereignty guarantees a putative universal equality for all modern subjects. Collectively these projects suggest that our contemporary moment is one in which the conditions of racial freedom and violence constitutive of modern slavery and colonialism and nineteenth- and early twentieth-century racial modernity-and upon which modern citizenship is foundedorganize the dialectic of contemporary knowledges. ${ }^{4}$ Though liberal political thought and current disciplinary practices advance a theorization of social, political, and racial violence as a pure means or instrumentality whose abolition is a matter of self-willing and moral consciousness, Frantz Fanon powerfully reminds us in his critique of Western-inspired understandings of revolutionary violence that these distinctly modern violences cannot be resolved through "national consciousness," the hegemonic ethical project of the modern state. ${ }^{5}$ Contrary to the revolutionary understanding of a freedom through violence, or the liberal hypothesis of a "post-racial" national modernity as a freedom from violence, critical ethnic studies refuses the reconciliation of a material politics of race to the racialized national state. The reconciliation of cultural subjects within the contemporary racialized and global division of labor to the ethical subject posited by the racial state, as well as by bourgeois revolutionary and liberal national practices of freedom, enables the "discovery" and persistence of a distinct monopoly of legitimate violence within modern social formations. Modern social sciences produce a "norm-ated" social totality, establishing the conditions for and the vectors of legitimate violence. Hence, the critiques within and of ethnic studies that sustain critical ethnic studies ask us to reappraise the possible meanings of race that our contemporary modernities cultivate and that are occluded by its normalization, dialectical meanings that negate the persistence of freedom and violence as the foundational structure of modern social, political, and cultural agency. ${ }^{6}$

These alternative meanings of race interrupt the forms of historical consciousness that sanction the racial state and its ontology as legitimate violence. They forward a critique of modern equality as the fulcrum of the state form, desubordinating alternative practices of alliance and collectivity otherwise repressed by liberal egalitarianism and state reform. To take only one example from our contemporary moment, a critical ethnic studies grasps that new social and political meanings and modes of inquiry must be cultivated to address the current legal, institutional, and cultural "equality" movement for so-called universal marriage and the "rights" of gays and lesbians to serve openly in the military at the dawn of our new century. To the degree that legal and disciplinary epistemologies analogize the "movement" for gay and lesbian equality within the state to the twentieth-century Civil Rights movement, critical ethnic studies must firstly historicize and account for the knowledge formations within which and through which gay and lesbian "equality" is imagined and pursued. These knowledge formations emerged out of the crisis of meaning and the state that mid-century Civil Rights struggles and global decolonization engendered within 
the disciplines and institutions of the West. From this perspective we can assess that the current extension of US constitutional subjectivity and legal identity to variously queer persons is dialectically related to the institutionalization of positivist multiculturalism across the disciplines and professional schools of the late modern university, the representative apparatus of legitimate knowledge. Positivist multiculturalism emerged in the epistemological fissures constituted by the global anti-racist movements of the twentieth century, establishing the norms, practices, and meanings that forcibly reconcile global anti-racist and Third World struggles to the putative universal history of the Western capitalist state. The racial repressions constituted by positivist multiculturalism and legal neutrality in the last thirty years have been central to the development of the popular epistemes and disciplinary knowledges that naturalize gay "personhood," the movement for equal rights, and the state recognition of queer "people." Yet, ironically, the constitutive analogizing of gay equality with the movement for African American Civil Rights persistently unleashes the specter of the twentieth-century Black Freedom movement, whose heterogeneous modes of comprehending race continue to haunt institutionalized and disciplinary multicultural positivism. ${ }^{7}$ Rather than claim the "queer" as a new subject of late modern US political modernity, critical ethnic studies comprehends the positivist domination of race as the very means by which a liberal, state-oriented political field re-articulates racial transformation to gendered, sexualized, and extraterritorial violences.

The 2008 US elections cycle-which heralded the election of the first African American president as well as the simultaneous defeat of so-called universal marriage rights in California (the country's most racially diverse and populated state) in the context of unpopular US wars and the failed neoliberal management of the globally deregulated, finance-dominated economy-has again restored crisis and contestation to positivist modes of knowing. The election results have stretched to the limit positivist accounts that would reduce California's diverse and historically multiplicitous publics and their practices to "voter behavior" in an attempt to explain the apparent paradoxes of "national" narratives of progress. To the degree that multicultural positivist practices of interpretation have once again marginalized diverse and "non-national" practices and meanings in their attempt to control the production of meaning of this social and political event, we can assess positivist multiculturalism as a central discursive formation in our contemporary political economy of dispossession and disposability. In contradistinction, critical ethnic studies points to how alternative epistemological accounts of race, or better, differing relations to our extant means of knowing, can defeat the fatal coupling of late modern US racial transformation with the growth of state, legitimate, and disciplinary violences against the non-contractual and deterritorialized publics of our contemporary, highly differentiated capitalist social formations. A rethinking of race as designating the material conditions of possibility of our modern ways of 
knowing and acting is crucial if we are to comprehend and change how political modernity has itself yielded liberal representative democratic states that repeatedly take horrendous freedoms with destructive violence.

Critical ethnic studies, then, is a project in the politics of knowledge, working with materialist epistemologies of race that seek to account for our relation to the conditions of epistemological form. Our disciplinary modes of knowing have themselves contributed to a certain resignation that the "resolution" of earlier and ongoing racial modernities through modern institutional citizenship is the limit of a politics of race. Yet, to the extent that contemporary citizenship has been determined by the defeats as much as by the successes of the struggles against persistent racial inequality and domination, the modern experience of race is neither an overcoming of violence $b y$ freedom, nor simply an extension of violence through freedom, but rather our eponymous and ambiguous contemporary modernity as a racialized freedom with violence-every expression of contemporary racial transformation is at once conjoined with substantively modern violences. Critical ethnic studies can help us rethink oppositional knowledges and practices in this age of a "freedom" with violence.

\section{NOTES}

1. See Saidiya Hartman, Scenes of Subjection: Terror, Slavery, and Self-Making in Nineteenth-Century America (New York: Oxford University Press, 1997).

2. See Ruth Wilson Gilmore, Golden Gulag: Prisons, Surplus, Crisis, and Opposition in Globalizing California (Berkeley: University of California Press, 2007), 85-86.

3. See Lisa Lowe and David Lloyd, eds., The Politics of Culture in the Shadow of Capital (Durham, NC: Duke University Press, 1997); Saskia Sassen, Globalization and Its Discontents: Essays on the New Mobility of People and Money (New York: New Press, 1999); Inderpal Grewal and Caren Kaplan, eds., Scattered Hegemonies: Postmodernity and Transnational Feminist Practices (Minneapolis: University of Minnesota Press, 1997); and Gayatri Spivak, "Diasporas Old and New: Women in the Transnational World," Textual Practice 10, no. 2 (1996): 245-269.

4. See Moon-Ho Jung, Coolies and Cane: Race, Labor, and Sugar in the Age of Emancipation (Baltimore: Johns Hopkins University Press, 2006); Stephanie Smallwood, "Commodified Freedom: Interrogating the Limits of Anti-slavery Ideology in the Early Republic," Journal of the Early Republic 24 (2004): 289-298; and Walter Johnson, Soul by Soul: Life inside the Antebellum Slave Market (Cambridge, MA: Harvard University Press, 2001).

5. See Frantz Fanon, "Concerning Violence," in The Wretched of the Earth, trans. Richard Philcox (New York: Grove Press, 2004).

6. See Roderick Ferguson and Grace Kyungwon Hong, eds., Strange Affinities: The Gender and Sexual Politics of Comparative Racialization (Durham, NC: Duke University Press, 2011). On the historical development and dominance of norm-based knowledges in the United States, see Roderick Ferguson, Aberrations in Black: Toward a Queer of Color Critique (Minneapolis: University of Minnesota Press, 2004), and Nayan Shah, Contagious Divides: Epidemics and Race in San Francisco's Chinatown (Berkeley: University of California Press, 2001).

7. On the Black Freedom movement, see Nikhil Pal Singh, Black Is a Country: Race and the Unfinished Struggle for Democracy (Cambridge, MA: Harvard University Press, 2006); on the critique of disciplinary retrenchment within legal studies, see Kimberlé Williams Crenshaw, "Race, Reform, and Retrenchment: Transformation and Legitimation in Antidiscrimination Law," Harvard Law Review 101, no. 7 (1988): 1331-1387. 